\title{
EFFECT OF HUDHUD CYCLONE ON THE DEVELOPMENT OF VISAKHAPATNAM AS SMART AND GREEN CITY - A CASE STUDY
}

\author{
VR Sankar Cheela ${ }^{1}$, Ramesh raju B $^{2}$, Gopala Raju SSSV ${ }^{3}$, KVGD Balaji ${ }^{4}$ \\ ${ }^{1}$ Assistant Professor, Department of Civil Engineering, MVGR College of Engineering, Vizianagaram \\ ${ }^{2}$ Associate Professor, Department of Civil Engineering, MVGR College of Engineering, Vizianagaram \\ ${ }^{3}$ Professor, Department of Civil Engineering, MVGR College of Engineering, Vizianagaram, \\ E-Mail: sssvgopalaraju@gmail.com, Ph No: 9492229222 \\ ${ }^{4}$ Professor, Department of Civil Engineering, GITAM University, Visakhapatnam
}

\begin{abstract}
The present study discusses on preliminary survey on the awareness levels of different classes of people on disaster alarming and management system. This provided fundamental initiative for developing a plan for green and smart city. 57\% of the survey included the participants from age group 15- 35 age and 43\% from age group above 35 years age. 49\% are from educational sector, $21 \%$ are from government and private sector, $30 \%$ from others. $31 \%$ are part of cyclones, $9 \%$ are part of floods, $59 \%$ are part of landslides. The survey revealed that $70 \%$ increase in the awareness levels on disaster alarming system. $50 \%$ people are aware of disaster management system before tsunami while it increased by $44 \%$ after tsunami. The technological development has catered a better scope in facing the disasters of this sort. The public private participatory approach would bring better results in developing a better disaster alarming, management and green city.
\end{abstract}

Key words: Disaster alarming system, Disaster management system, smart city $* * *$

\section{INTRODUCTION}

Hudhud was one of the two strongest tropical cyclones of 2014 within the Bay of Bengal. On October $6^{\text {th }}, 2014$ near Andaman Sea under the influence of the upper air cyclonic circulation the storm originated as a low pressure system. Open water shaped a constructive atmosphere for formation of depression. Tropical cyclone formation alert (TCFA) ${ }^{[1]}$ was issued by the Joint Typhoon Warning Center (JTWC). At long island, Andaman depression made its first landfall. The intensity of the storm increased at a rapid rate after entering the Bay of Bengal. On October $10^{\text {th }}$, 2014 with moderate wind shear the tropical cyclone formed a microwave eye feature escalating its impact ${ }^{[2,3,4]}$. With a minimum central pressure of $950 \mathrm{mbar}(28.05 \mathrm{inHg})$ and three-minute average wind speeds of $185 \mathrm{~km} / \mathrm{h}(115 \mathrm{mph})$ the cyclone underwent rapid intensification and developed an eye at its center on October $11^{\text {th }}, 2014$. Hudhud underwent landfall near Visakhapatnam on October $12^{\text {th }}$, 2014 near $17.7^{\circ} \mathrm{N} 83.3^{\circ} \mathrm{E} .^{[5,6,7,8]}$ Peak strength of 3 minute wind speeds of $175 \mathrm{~km} / \mathrm{h}$ and minimum central pressure of 960mbar were reached. It drifted northwards causing profound rainfall in the areas of Madhya Pradesh, Uttar Pradesh and Nepal. Prevalent snow fall in Uttar Pradesh and Nepal occurred in later stages. It has been classified as category 4 under saffir- simpson scale. The government alerted nine out of thirteen districts of Andhra Pradesh. It declared and alert sounding nine. Half a million people were evacuated and were put in the relief camps. National Disaster Response Force (NDRF) mobilized 35 teams in Andhra Pradesh and Odisa. 38 trains were cancelled on October $12^{\text {th }}, 2014$. Fishermen were warned and were evacuated. The National Highway, one of the major roads traversing was shut down after trees were uprooted due to storm force. Within hours of hitting the coast, the cyclone severed and damaged Naval Dockyard, Vizag steel plant, Hindustan Petroleum Limited and other major industries in the city. Visakhapatnam Airport was flooded, roof of the terminal was torn, and radar and navigational aids were destroyed. Strong winds and heavy rainfall uprooted trees, damaged power supply and communication systems, leading to disruption in power supply and connectivity ${ }^{[9,10]}$. With the extensive damage the residents of coastal districts were without power supply and communication for an average period of ten days. The government has undertaken initiatives in restoring the basic needs ${ }^{[11,12]}$.

\section{STUDY AREA}

Visakhapatnam is also known as City of Destiny, is one of the swiftly emergent metropolitan cities in south India. Topographically, Visakhapatnam is located north east corner

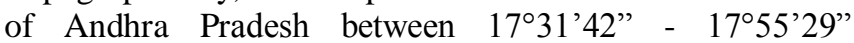

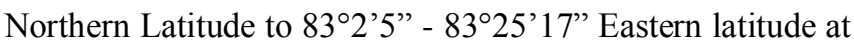
an average elevation of 3 meters above sea level surrounded by Kailasa Hills on North, Yarada hills on South, Narva hills on west and Bay of Bengal on East. The city gets moderate rainfall of $1202 \mathrm{~mm}$ largely between June to October. On account of its elevation, Visakhapatnam has hot and humid climate comparable to those of other temperature regions. The city covers the local planning area of 544 sq. kms. The Greater Visakhapatnam Municipal Corporation (GVMC) consists of Municipal Corporation of Visakhapatnam, 32 merged villages and Gajuwaka municipality. The population of Visakhapatnam as per 2001 census is 9.69 lakhs while that in 2011 is 17.06 lakhs 
indicating the growth of population as $79 \%$ during 2001 to 2011. Merging of the surrounding villages and municipalities is a significant contributing factor for the rapid increase in percentage of population. GVMC has been divided into six zones consisting of 72 wards. The GVMC is concerned with the prime areas of public health, solid waste management including health care waste, sanitation and education. Participatory approach is adopted to develop Visakhapatnam into smart city.

\subsection{Screening Methodology}

Development projects require mitigation, evaluation and assessment of various factors which play a vital role in decision making. Among various alternatives available for nurturing city of destiny into smart city it is necessary to undertake a preliminary assessment in reaching to a better solution. In the process of impact assessment the preliminary process embark on with screening process in which various surveys are to be conducted. As part of this process an initial study was performed with a set of questions for deciding various options for developing a better city and disaster management system. The following is set of first round questions:

1. Share your experiences about previous disasters occurred in Visakhapatnam.

2. Rate and share your views on disaster alarming system.

3. Rate and share your views on disaster management system.

4. Share your views in developing Green \& Smart Visakhapatnam.

\section{RESULTS AND DISCUSSIONS}

\subsection{Classes Of Participants Based On Age Group}

Preliminary surveys were conducted in the study area for a period of five days for collecting the views from different classes of people. The criteria one for dividing the class of participants was divided based on the age group. $15-25$ years, 25-35 years, 35-50 years, 50-60 years, greater than 60 years were considered. Figure 1 represents the gender wise percentage of people participated. $36 \%$ male and $24 \%$ female from $15-25$ age group, $26 \%$ male and $28 \%$ female from $25-35$ age group, $18 \%$ male and $28 \%$ female from 35 50 age group, $13 \%$ male and $14 \%$ female from $50-60$ age group, $8 \%$ male and $7 \%$ female from greater than 60 age group participated in the survey. Overall $57 \%$ of the survey included the participants from age group 15- 35 age and $43 \%$ from age group above 35 years age.

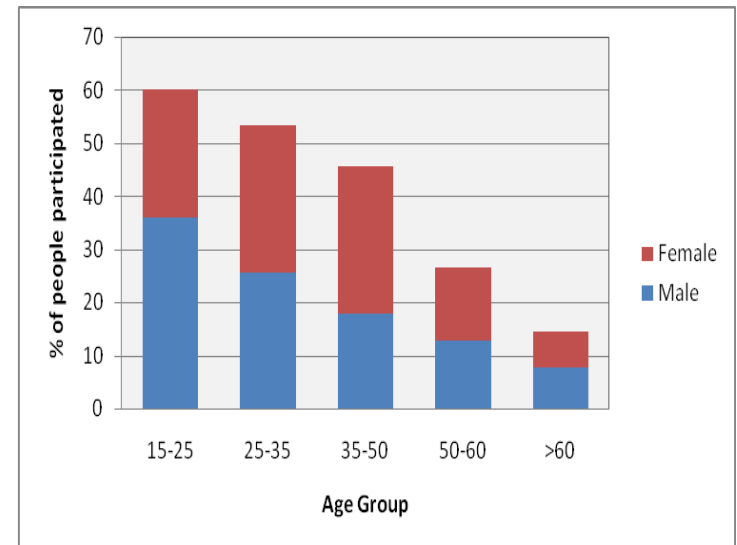

Figure 1: Gender Vs. Age Group

\subsection{Classes of participants based on profession}

The criteria two for dividing the class of participants was divided based on the profession. It is classified into Students, government sector, private sector, academics and others. Figure 2 represents the profession wise percentage of people participated. $41 \%$ male and $38 \%$ female are students, $13 \%$ male and $3 \%$ female are working in government sector, $15 \%$ male and $7 \%$ female are working in private sector, $10 \%$ male and $7 \%$ female are working as academicians, $21 \%$ male and $45 \%$ female are classified as others which included self financed, non-working people. Overall $49 \%$ are from educational sector, $21 \%$ are from government and private sector, $30 \%$ from others.

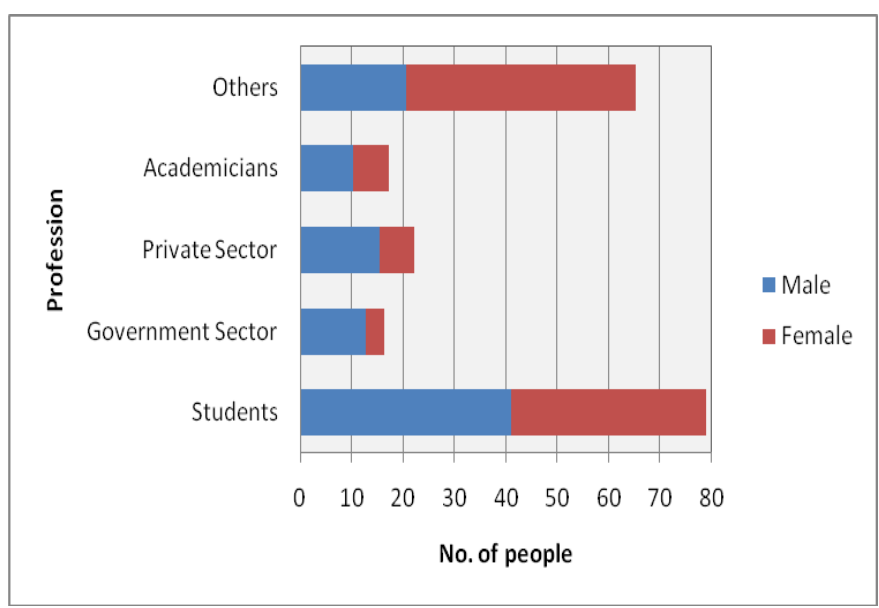

Figure 2: Gender vs. Profession

\subsection{Disasters occurred in Visakhapatnam}

After the state division, Visakhapatnam has been recognized as one of the central zones for developing the industrial corridor. The government has been planning to nurture this city as a smart city. During this process period the place has been affected by one of very severe cyclone named Hudhud. The government has decided to start from scratch and take initiatives in shaping into green and smart city from the day after this cyclone. As the location of the city lies near to sea it is necessary to understand about the various disasters occurred previously. Figure 3 represents the percentage of people who are part of disasters occurred in Visakhapatnam. 
As part of this the participants shared their experiences about the past disasters. $31 \%$ are part of cyclones, $9 \%$ are part of floods, 59\% are part of landslides occurred and no hurricanes and typhoons occurred. They shared their experiences about the severe cyclone in the year 1977, Tsunami in year 2004 which are considered to be most disastrous disasters occurred before. Odisa cyclone in year 1999, Cyclone Phailin, Cyclone Nilofar and many more included the list of tropical cyclones affected Visakhapatnam. As the city is covered by the hills in the three directions, during rainy season landslides occurred.

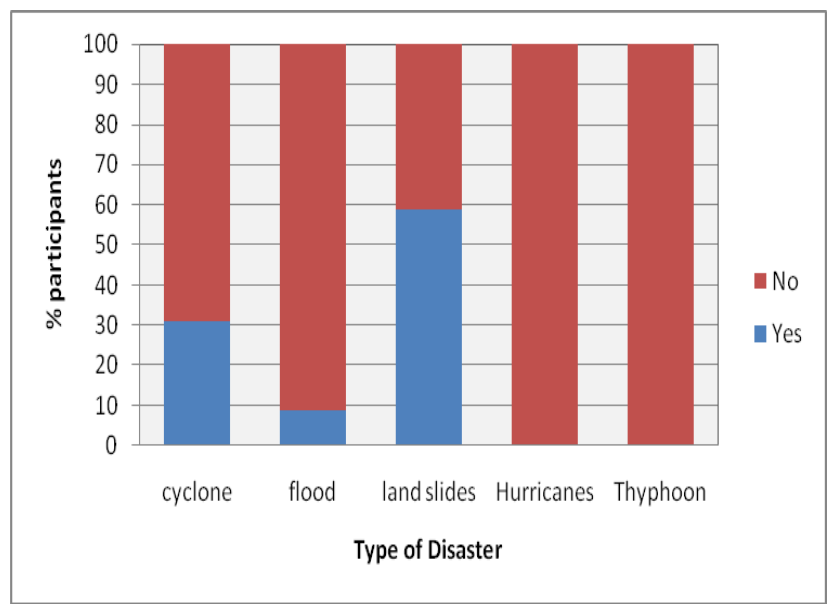

Figure 3: Type of disaters occurred in Visakhapatnam

\subsection{Disaster alarming system for Hudhud}

Disaster alarming system plays a major role in creating awareness to the residents of the affected area during the disaster period. A survey was made to understand about the awareness system among various categories of people. Figure 4 represents the percentage of awareness among people about disaster alarming system. During tsunami period $14 \%$ of people are aware of disaster alarming system, $44 \%$ people are having an idea about alarming system while $42 \%$ people are not aware of these systems. During Hudhud cyclone $85 \%$ of people are aware of disaster alarming system, $3 \%$ people are have a idea about alarming system while $12 \%$ people are not aware of these systems. The participants expressed that it is after tsunami many efforts were made to make people aware of the alarming systems and high initiatives were taken by the Indian Metrological Department (IMD) in estimating and forecast the disasters prior hand. The dynamics of the Hudhud cyclone were foretold by IMD before 5 days. The participants expressed that the alarming system was excellent and the cyclone reached the landfall as predicted which played a major role in reduction of death toll to a great extent.

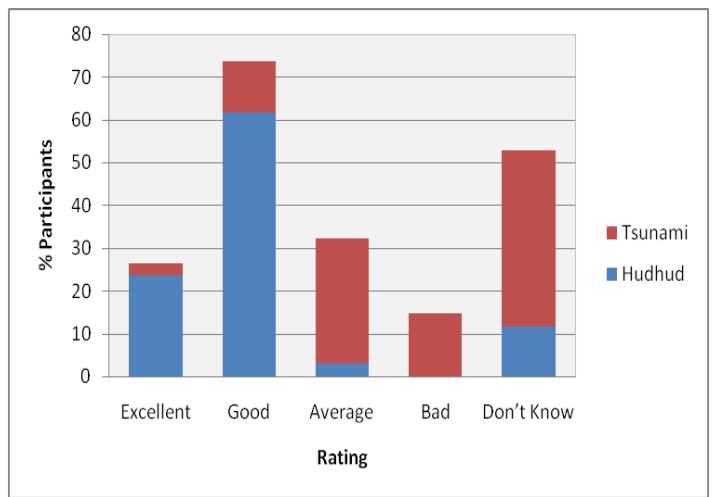

Figure 4: Percentage of awareness among people about disaster alarming system

\subsection{Restoration and rehabilitation activities}

Restoring of transportation, communication and power supply in a very short span of time was achieved due to the awareness created by the disaster management system initiatives.

A survey was made to understand about the awareness system among various categories of people. Figure 4 represents the percentage of awareness among people about disaster management system. During cyclones of this sort previously $38 \%$ of people are aware of disaster management system, $9 \%$ people are have an idea about this system while $53 \%$ people are not aware of these systems. During tsunami period $50 \%$ of people are aware of disaster management system, $15 \%$ people are have a idea about this system while $35 \%$ people are not aware of these systems. During Hudhud cyclone $94 \%$ of people are aware of disaster management system, 3\% people have an idea about alarming system, 3\% people are not aware of these systems. The survey provided that the government has taken better initiatives after tsunami effect in making people to have an awareness to sustain the life after disaster. The initiatives and technological advancements during this span have provided a better platform for speedy recovery of the city from the disaster. Public-Private participation created hand-in-hand for the government to commence enhanced rehabilitation activities.

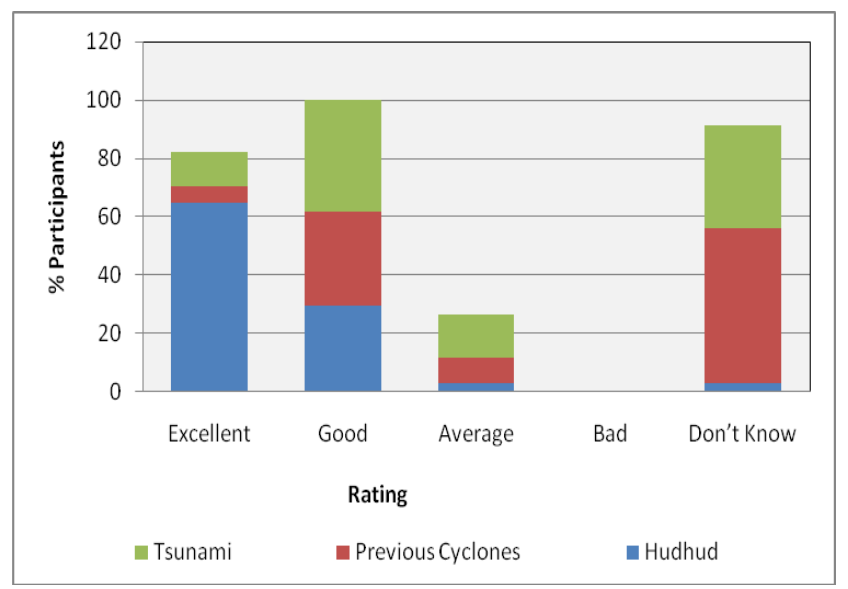

Figure 5: Percentage of awareness among people about disaster management system 


\subsection{Developing Green and Smart Visakhapatnam.}

Eight key aspects of the smart city include governance, energy, building, mobility, infrastructure, technology, healthcare and citizen. The smart city utilizes information and communication technologies for the development of physical infrastructure engaging the residents of the city to participate in innovative designing and development of strong economic, social and cultural developments ${ }^{[13,14,15]}$. The development shall include low cost, affordable housing, transit oriented development, e-solutions for various activities and inclusive of social and commercial architecture. The smart city plan shall include electrification of all households with power availability for at least 8 hours per day, intelligent transport systems, safe waste disposal units, effective disaster management systems and risk reduction technologies, Electric vehicle charging stations in all urban areas and along all state and national highways, utilization of renewable sources of energy ${ }^{[16,17]}$.

\section{CONCLUSIONS}

1. The surveys reveled that that $31 \%$ are part of cyclones, 9\% are part of floods, $59 \%$ are part of landslides occurred and no hurricanes and typhoons occurred in previous years.

2. Awareness on disaster alarming and risk reduction technologies are to be encouraged and initiatives are to be taken through public private participation

3. The disaster management system should be well connected to the people through information and communication methodologies.

4. The plan of shaping the city into smart and green city shall include the governance, energy, building, mobility, infrastructure, technology, healthcare aspects into consideration.

\section{REFERENCES}

1. "Tropical Cyclone Formation Alert - Issued at 1330 UTC, 7 October 2014.". Joint Typhoon Warning Center.

2. "Tropical Weather Outlook for North Indian Ocean Issued at 0600 UTC of October 7, 2014.". India Meteorological Department.

3. "Cyclonic Storm Hudhud over north Andaman Sea \& adjoining southeast Bay of Bengal.". India Meteorological Department.

4. "Very Severe Cyclonic Storm, HUDHUD over the Bay of Bengal (7-14 October 2014): A Report". India Meteorological Department.

5. "Hudhud intensifies: Andhra Pradesh, Odisha on high alert". India Today. India Today.

6. "Cyclone Hudhud Effect: 38 Trains Cancelled on October 12". 11 October 2014.

7. "Cyclone Hudhud Heads for Odisha, After Battering Andaman and Nicobar Islands". NDTV. 8 October 2014.

8. "Cyclone Hudhud: 1.11 lakh people in Andhra Pradesh evacuated".
9. "Cyclone warning centre at Vizag also hit by Hudhud". news. biharprabha.com. IANS. 12 October 2014.

10. "Relief operations begin in cyclone-hit Andhra". 13 October 2014.

11. "Hudhud rips through Visakhapatnam airport". Times of India (Hyderabad). 14 October 2014.

12. "Cyclone Hudhud triggers Heavy rainfall in Southern Odisha". news. biharprabha.com. IANS. 12 October 2014.

13. Beck, A. and Stave, K. (2011). "Understanding urban quality of life and sustainability," presented at the 29th International Conference of the System Dynamics Society Washington, DC, July

14. Bengtsson, F. and AŁgerfalk, P. J. (2011). "Information technology as a change actant in sustainability innovation: insights from Uppsala," Journal of Strategic Information Systems, vol. 16 (4), 96-112

15. Brinkman, J. (2011). "Supporting sustainability through smart infrastructures: the case of Amsterdam," Network Industries Quarterly, vol. 13 (3)

16. Hutchins, M. J. and Sutherland, J. W. (2008). "An exploration of measures of social sustainability and their application to supply chain decisions," Journal of Cleaner Production, vol. 16, 1688-1698

17. Munda, G. (2006). "Social multi-criteria evaluation for urban sustainability policies," Land Use Policy: Elsevier Ltd, vol. 23, 86-94 